\author{
Andrii GUDZYK, \\ orcid.org/0000-0001-6163-4953 \\ Postgraduate Student at the Department of Performing Arts \\ Vasyl Stefanyk Precarpathian National University \\ (Ivano-Frankivsk,_Ukraine)sax_a.gudzyk@yahoo.com
}

\title{
SIMULATION OF ARTICULATION AND RHYTHMIC TECHNIQUES ON THE SAXOPHONE
}

The article describes the physical modeling of wind instruments provides digital sound synthesis based on a set of parameters that have a direct physical interpretation. Going beyond sound synthesis programs, such models can be used to analyze the mechanism of sound generation.

Blowing into the mouthpiece of a saxophone allows the player to control the oscillation of the reed by creating a pressure difference across its surface. When the reed oscillates, it creates an alternating opening and closure to the bore, resulting in a periodic train of pressure pulses, or a reed pulse sequence, that enters into the instrument bore.

The propagation of pressure waves in the cylindrical and predominantly conical sections of the saxophone may be modeled in one dimension using a digital waveguide, with a bi-directional delay line accounting for the acoustic propagation delay, and additional filter elements accounting for losses distributed along the length of the instrument and at the boundaries.

Though open tone holes, used by the player to control sounding pitch, do complicate the issue, they can still be modeled within a one-dimensional waveguide context by lumping their effects at waveguide boundaries (i.e. with the bell).

For wind instruments, one of the primary ways in which a performer controls sound production, aside from changing pitch using instrument tone holes/keys, is by changing the air flow into the bore through alterations of blowing pressure and embouchure. In saxophone playing, estimation of the signal generated by the reed, the reed pulse, by inverse filtering the effects of the instrument can, therefore, yield a signal holding many of the more subtle playing parameters.

In this publication, we approach also the problem of visualizing the playing of the saxophone from the standpoint of the psychomotorical skills of the instrumentalist performer, due to the nature of the instrument, the specifics of sound production on it, as well as the structure of the intonational-artistic image - the subject of imitation, embodiment and communication.

Key words: reed, mouthpiece, sound modeling, articulation, method, motor skills, rhythm, strokes.

\author{
Андрій ГУДЗИК, \\ orcid.org/0000-0001-6163-4953 \\ аспірант кафедри виконавського мистецтва \\ Прикарпатського національного університету імені Василя Стефаника \\ (Івано-Франківськ, Украӥна) sax_a.gudzyk@yahoo.com
}

\section{МОДЕЛЮВАННЯ АРТИКУЛЯЦЇ̈ ТА РИТМІКИ НА САКСОФОНІ}

У статті охарактеризовано фізичне моделювання артикуляиії на саксофоні, щзо забезпечує иифровий синтез звуку на основі набору параметрів, які мають безпосередню фізичну інтерпретацію. Виходячи за рамки програм синтезу звуку, такі моделі можемо використовувати для аналізу механізму генерації звуку.

Повітряна атака в мундштук саксофона дає змогу гравцеві контролювати коливання тростини, створюючи різницю тиску на його поверхні. Коли тростина коливається, вона створює поперемінний отвір $і$ закриття, що приводить до періодичнӧ послідовності імпульсів тиску або послідовності імпульсних коливань, які утворюють повітряний стовп в інструменті і формують звук.

Поширення хвиль тиску в ииліндричній та переважно конічній секціях саксофона можуть бути змодельовані в одному вимірі за допомогою ичиррового хвилеводу з двонаправленою лінією затримки, щьо враховує затримку поширення звуку, та додатковими елементами фільтра, щчо враховують втрати, розподілені вздовж довжини інструменту.

Незважаючи на те, щзо відкриті звукові отвори, які використовуються виконавцем для управління висотою звучання, ускладнюють проблему, вони все одно можуть бути змодельовані в одновимірному контексті хвилеводу шляхом об' сднання їх ефектів на межі хвилеводу (тобто з раструбом).

Щодо духових інструментів, то одним із основних способів, за допомогою якого виконавець контролює звучання, крім зміни висоти тону за допомогою клапанів/клавіш інструменту, є зміна потоку повітря в отвір за допомогою зміни тиску подачі повітря та амбушура. Таким чином, під час гри на саксофоні оцінка сигналу, щз генерується тростиною, иляхом зворотного фільтрування ефектів інструменту, може давати сигнал, щзо утримує багато найтонших параметрів гри. 
У публікації ми підходимо також до вирімення проблеми візуалізації гри на саксофоні з позицій психомоторних навичок виконавця-інструменталіста, щуо обумовлено природою інструменту, специфікою звукоутворення на ньому, а також структурою інтонаційно-художнього образу - предмету наслідування, втілення та спілкування.

Ключові слова: тростина, мундштук, моделювання звуку, артикулячія, прийом, моторика, ритміка, итрихи.

Statement of the problem. Methods in both frequency and time domains provide a modeling system for the synthesis of stationary oscillations. The latter, also suitable for nonlinear applications, are able to provide transient behavior of the system.

Of particular interest is whether the forms of measurements are consistent with the physical model with the measurements, and how the manipulator of control parameters plays at the beginning of the notes.

Transitions are very important when it comes to identifying or evaluating musical instruments, because they are related to the nature of a particular instrument and how easy it is to play.

Recent attempts to understand the intricacies of transient effects in wind instruments range from complex measurements to simplified models and to deal with transient processes of attack and decay.

The properties of instrumental performing art determine similar and at the same time different from vocal performance methods of training an instrumentalist in the aspect of educating his skills, intonation and artistic artistry, the formation of the artistic universe as a whole (Adamyan, 1978: 165).

The modern aesthetics of concert activity in different genres and directions of musical and performing creativity actualizes the problem of visual artistic intonation-representation of academic art.

Ukrainian musicologists are increasingly addressing this problem in the following aspects: "external (kinematic) motor image" (Yu. Bai), "motor-plastic intonation", "bodily-motor energy movements" (M. Davydov), "theatricality" (A. Chernoivanenko, S. Savruk) and others.

Research analysis. The paper analyzes the transition between two stationary saxophone tones while playing the portato, using measurements of the pressure in the mouthpiece and the bend of the cane.

Trying to resynthesize such tones, the parameters of the modern physical model are adapted accordingly. In the instrumental and performing arts, motility is actualized in a huge number of small and large movements: small (finger) and large (wrist) techniques, as well as in body movements that accompany the embodiment of the character of the image.

To carry out the motor part of the artistic "work", the saxophonist needs will in many of its manifestations. It is known that "freedom is a conscious organization and self-regulation of one's activities and behavior, aimed at overcoming difficulties in achieving goals.

The purpose of the article is the physical modeling of the saxophonist's sound and its interaction with the process of formation and functioning of special movements and techniques on the saxophone.

Presenting main material. Articulation in wind instruments is usually performed by language and is achieved by direct modulation of cane oscillations, which leads to modification of the flow through the channel "cane-mouthpiece" (Walstein, 2012: 31).

The second method of articulation is to directly modulate the air flow by regulating the purge pressure applied to the cane. Such air-separated tones may give rise to a similar but not identical musical phrase. Therefore, an attempt at physical modeling to capture the above articulation techniques should be able to distinguish between speech and air-separated tones.

The experiments were performed on an alto saxophone using a Vandoren A45 mouthpiece and a Vandoren cane.

The bending of the cane was measured using a strain gauge. The internal pressure in the mouthpiece was measured by inserting a condenser microphone into the mouthpiece so as not to affect the player's earbuds.

In order to verify that the blown pressure remained unchanged in the case of speech tones and changed for tones separated by air, it was measured using a Technosound 9853 probe.

During the interaction of the tongue, the oscillations of the cane do not stop completely, and the same is held for pressure on the mouthpiece. The action of the tongue seems to increase the cushioning of the cane and change its position of equilibrium, which leads to a much smaller amplitude of vibration.

In front of the tongue of the cane tongue has one clamped and one free limit state, and the increase in pressure in the mouthpiece tends to open the cane. When the tongue presses on the cane, the increase in pressure in the mouthpiece tends to deform the cane, bending it so that it seems to close.

This effect is absent in the case of air tones. In fact, the pressure waveforms are significantly different for each articulation technique. This indicates the fact that the influence of the performer's tongue is not limited to the modulation of the air flow to the mouthpiece.

Simulation of cane vibrations during articulation can be achieved by modulating the physical model to 
explain how the performer affects the system while adjusting its ear cushion. An attempt to include the effect of the performer's tongue involved the addition of a second damped system of spring masses that interacts with the oscillations of the cane (Gilbert, 1990: 39).

All performing technique is a connection between the articulatory abilities of a musician and an objective expression of conscious phenomena of the psyche: experiences, desires, motivations, needs, goals in accordance with the artistic idea, creative artistic tasks.

The motility and rhythmic of the instrumentalist musician is an expression of deep internal psychological processes and therefore in relation to musical performance, axiomatically based on creative psychology, we speak of psychomotor skills as a creative volitional process, objectifies all forms of mental reflection with their movements (Rode, 1999: 38).

Knowledge of the laws of psychomotor and rhythmic is especially important in instrumental performance, which requires high accuracy, proportion, rhythmicity and coordination of movements.

The most general psychological classification of performing movements provides for their division into the following groups: the main - the minimum necessary to achieve the sound goal, are carried out in the most favorable conditions of performance; corrective - clarifying the main movements in accordance with the deviations of the conditions of performance from the most favorable; additional - not related to sound, but necessary due to the presence of side factors during the performance; extra - unnecessary, usually interfere with basic movements; erroneous - performed instead of the correct movements of the first three groups and not reaching the goal (Delangle, 1998: 10).

The process of formation and functioning of special movements of performers of instrumentalists of all without exception instrumental specialties is based on optimal regularities:

- coordinated freedom;

- clear representation of the movement;

- a sense of "weight" of the game machine;

- purposefulness for the sound-intonation result;

- expediency of the trinity of intonation-artistic, motor and biomechanical spheres;

- economy;

- naturalness, aesthetics, content, characteristic, organic appearance of motor actions;

- taking into account the individual psychophysiological characteristics of the performer;

- synthesis of auditory and motor control in the perception of movement.
Conscious selection - the construction of special movements in the work on the main expressive means of music of the traditional academic direction - the melody follows the following scheme:

1) concretization of the sound goal-image, its syntax and pragmatics;

2) the choice of the standard of the form of the movement adequate to the sound purpose;

3) search for the optimal ratio of intonation-artistic and motor expediency, taking into account the individual capabilities of the performer;

4) automation of correct movements in order to achieve organic unity between sound intonation and motor image spheres as an element of psychotechnics in the aspect of communication stability: auditory representation $\rightarrow$ form of movement $\rightarrow$ form of sound;

5) achievement of psychophysiological (psychotechnical) dominance at a leading role of musical and figurative sphere, "in art of the master is result of expediently organized musical and game process".

Improvement of special (basic) and additional forms of movements are carried out in the following directions:

- the main types and elements of artistic (expressive-speech) technique - the above historical forms of intonation: scales, arpeggios, consonance-chords (including on some wind instruments), jumps, melisms, figurations, ornamentation, anniversaries, diminutions, chants, trails, coloring, rehearsals and more;

- bar (articulation) technique;

- mastering the skills of playing the simplest characteristic "formulas of microstructural intonation" (M. Davydov) as classical models of the embodiment of musical and energetic meanings;

- working out of melodic structures of high "intonation-artistic fund" of music - excerpts of musical works as standards of artistic-aesthetic images in unity of internal representation-experience and external game embodiment.

The proposed method of forming the culture of musical and game movements as the basis of artistic technique (and artistic algorithm) of the performerinstrumentalist contributes to:

- stability of the motor sphere of the musicalgame process of the performer-instrumentalist;

- intonation expressiveness;

- semantic clarity of the sound model-standard, "visibility" of musical syntax (especially in the cantilena)

- content and artistry of the performing artistic volitional act.

Conclusions. Summarizing the above, we can state that by modeling the speech effect, changing the mechanism of vibration of the cane, rather than the 
purge pressure, you can simulate the pressure signal in the mouthpiece, similar to the measured one.

The evolution of signals has the same profile both during attenuation and during attack. When only the purge pressure is modified, the simulated pressure signal is completely different, which also occurred when comparing the measured signals.

In this study it was possible to record the interaction of the cane without the additional complexity of the physical model. Therefore, the model itself remains unchanged, and the effect of airflow modulation changes.

The following variations are used:

- the balance of the cane hole decreases because the tongue tends to close the cane;

- the internal attenuation of the cane increases when the tongue comes in contact with it;

- the pressure above the cane flow is expected to increase due to a strong reduction in the hole; the pressure returns to the level of the blowing pressure with the release of the cane.

In the case of air tones, only the purge pressure is regulated.

Estimating the parameters of a physical model based on natural sounds can provide useful information about how the performer controls his instrument.

In this paper, an attempt is made to study how the parameters of the saxophone cane are manipulated during the transition processes of articulation on the saxophone.

Two different articulation techniques (with and without the use of the tongue) were simulated, as well as the pressure signals in the mouthpiece compared to the measurements in real playing conditions.

Depending on the personality of the performer, the stage of training, a specific piece, intuitive-unconscious or consciously-formalized types of work on motor skills may come to the fore.
As you know, the problem of the image of movement and its role in the regulation of motor acts is the central problem of the psychology of correct movements. In this regard, in the system of education and training of a performer-instrumentalist, the importance of ideomotor for the process of educating correct movements increases immeasurably.

All executive movements are controlled by ideas and perceptions, and the quality of movements depends on the quality of perceptions of the performer himself (sensorimotor skills). Performing movements are perceived and controlled not only by the performer himself, but also evaluated by the viewer-listener.

The visual picture of special semantically significant executive movements, not only provide an intonation-sound process, but also self-sufficiently express the meaning of musical works, in its organic unity guarantees an understanding of the musical work performed, gives the viewer-listener an idea of his artistic technique, virtuosity, artistic image of the work, artistry in general.

The performer's behavior, expressed in his movements, is visually manifested from the moment of his appearance on the stage, which is an integral artistic component of the performance itself, and the playing movements are aimed not only at extracting sound, but also at preparing an extract of the transceiving intonation and at stopping its sounding, at experiencing pauses, which together make up the motor (energy) structure of intonation.

The main thing here is the energetic figurative parallelism, the harmony between the structure of the intonation-artistic flow and the structure of psychophysiological artistic actions, behavior, communication of the performer-musician with the instrument and the audience.

\section{BIBLIOGRAPHY}

1. Абдуллин Е. Б. Методология - путь к творчеству : учебное пособие. Москва, 1995. 256 с.

2. Аврамкова И. С. Гид в музыкальном общении: исполнитель - слушатель : научное пособие. Санкт-Петербург, 2001. $230 \mathrm{c}$.

3. Адамян А. А. Вопросы эстетики и теории саксофонного искусства : монография. Москва, 1978. 165 с.

4. Адорно Т. Н. Социология музыки : учебное пособие. Москва, 1999. 361 с.

5. Алексеев А. Д. Интерпретация музыкальных произведений : учебник. Москва, 1984. 156 с.

6. Деркач А. А., Зазыкин В. Г. Акмеология : учебник. Санкт-Петербург, 2003. 198 с.

7. Delangle C. History of the vibrato on saxophone. Australian Clarinet and Saxophone. 1998. Vol. 15. № 3. P. 5-11.

8. Gilbert J. Calculation of stationary oscillations of a saxophone cane using the technique of harmonic balance. Journal of the Acoustic Society of America. 1990. Vol. 88. № 28. P. 35-41.

9. Walstein M. Estimation of clarinet reed parameters by inverse modeling. Acta Acustica. 2012. Vol. 51. № 9. P. $29-39$.

10. Fletcher N., Rossing T. Physics of Musical Instruments : textbook. New York, 1998. P. 98.

11. Sommerfeldt S. W. Strong Modeling of the player-saxophone system. Journal of the Acoustic Society of America. 1988. Vol. 72. № 12. P. 19-28.

12. Smyth T., Abel J. S. Toward an estimation of the clarinet reed pulse from instrument performance. Journal of the Acoustic Society of America. 2012. Vol. 131. № 35. P. 47-48. 
13. Smyth T., Cherla S. Saxophone by model and measurement : textbook. Copenhagen, 2012. P. 59.

14. Smyth T., Abel J. Estimating waveguide model elements from acoustic tube measurements. Acta Acustica. 2009. Vol. 23. № 10. P. 19-23.

15. Rode X. Inversion of the physical model of the pipe : textbook. Arizona, 1999. P. 38.

\section{REFERENCES}

1. Abdullin E. B. Metodologiya - put k tvorchestvu. [Methodology - the path to creativity]. Tutorial. Moscow, 1995. p. 256 [in Russian].

2. Avramkova I. S. Gid v muzykalnom obschenii. [Guide in musical communication: performer - listener]. Research guide. St. Petersburg, 2001. p. 230 [in Russian].

3. Adamyan A. A. Voprosyi estetiki i teorii saksofonnogo iskusstva. [Questions of aesthetics and theory of saxophone art]. Monograph. Moscow, 1978. p. 165 [in Russian].

4. Adorno T. N. Sotsiologiya muzyki. [Sociology of music]. Textbook. Moscow, 1999. p. 361 [in Russian].

5. Alekseev A. D. Interpretatsiya muzyikalnyh proizvedeniy. [Interpretation of musical works]. Textbook. Moscow, 1984. p. 156 [in Russian].

6. Derkach A. A., Zazyikin V. G. Akmeologiya. [Acmeology]. Textbook. St. Petersburg, 2003. p. 198 [in Russian].

7. Delangle C. History of the vibrato on saxophone. Australian Clarinet and Saxophone. 1998. Vol. 15, № 3. P. 5-11.

8. Gilbert J. Calculation of stationary oscillations of a saxophone cane using the technique of harmonic balance. Journal of the Acoustic Society of America. 1990. Vol. 88, № 28. P. 35-41.

9. Walstein M. Estimation of clarinet reed parameters by inverse modeling. Acta Acustica. 2012. Vol. 51, № 9. P. $29-39$.

10. Fletcher N., Rossing T. Physics of Musical Instruments: textbook. New York, 1998. P. 98.

11. Sommerfeldt S., Strong W. Modeling of the player-saxophone system. Journal of the Acoustic Society of America. 1988. Vol. 72, № 12. P. 19-28.

12. Smyth T., Abel J. S. Toward an estimation of the clarinet reed pulse from instrument performance. Journal of the Acoustic Society of America. 2012. Vol. 131, № 35. P. 47-48.

13. Smyth T., Cherla S. Saxophone by model and measurement : textbook. Copenhagen, 2012. P. 59.

14. Smyth T., Abel J. Estimating waveguide model elements from acoustic tube measurements. Acta Acustica. 2009. Vol. 23, № 10. P. 19-23.

15. Rode X. Inversion of the physical model of the pipe : textbook. Arizona, 1999. P. 38. 